\title{
CXXC5 Gene
}

National Cancer Institute

\section{Source}

National Cancer Institute. CXXC5 Gene. NCI Thesaurus. Code C152030.

This gene plays a role in the regulation of apoptosis, signaling pathways and gene expression. 